\title{
The influence of canine brucellosis on morphofunctional features of epididymal spermatozoa: case report
}

[Influência da brucelose canina nos aspectos morfofuncionais de espermatozoides epididimários: relato de caso]

\author{
D.S.R. Angrimani ${ }^{1}$, C.F. Lúcio $^{1}$, J.D.A. Losano ${ }^{1}$, M.M. Brito ${ }^{1}$, R.A. Silva Júnior ${ }^{2}$, \\ L.B. Keid ${ }^{2}$, M. Nichi ${ }^{1}$, C.I. Vannucchi ${ }^{1 *}$ \\ ${ }^{1}$ Faculdade de Medicina Veterinária e Zootecnia - USP - São Paulo, SP \\ ${ }^{2}$ Faculdade de Zootecnia e Engenharia de Alimentos - USP - Pirassununga, SP
}

\begin{abstract}
The present work reports a clinical case of a mongrel dog, with serological diagnosis of brucellosis, from which epididymal sperm analysis was performed. Sperm samples were collected from different segments of the epididymis (tail, corpus, and caput). Sperm samples were evaluated for computer-assisted motility analysis (CASA), spermatic morphology, mitochondrial activity and sperm plasmatic membrane and acrosomal integrity. Changes in sperm movement patterns were found (progressive motility, percentage of rapid sperm, percentage of rapid velocity, average pathway, curvilinear velocity, velocity straight line, amplitude of lateral head displacement, straightness and linearity), increase of total morphological defects $(51 \%)$ and absence of sperm mitochondrial activity $(20 \%)$ were verified, especially for cauda epididymides. We highlight that such changes can contribute to clinical diagnosis of Brucellosis in dogs and to the use of epididymal sperm in reproductive biotechnologies.
\end{abstract}

Keywords: dog, Brucella canis, epididymal sperm

\section{RESUMO}

Relata-se o caso de um cão mestiço, com diagnóstico sorológico para brucelose canina, a partir do qual foram realizadas análises do sêmen epididimário. As amostras espermáticas foram coletadas dos diferentes segmentos epididimários (cabeça, corpo e cauda). Foram realizadas as avaliações de motilidade computadorizada do sêmen (CASA), morfologia espermática, atividade mitocondrial, integridade das membranas plasmática e acrossomal. Houve alteração no padrão de movimentação espermática (motilidade progressiva, espermatozoides rápidos, velocidade média da trajetória, velocidade curvilínea, velocidade linear progressiva, amplitude de deslocamento lateral da cabeça, retilinearidade e linearidade), aumento do total de defeitos morfológicos (51\%) e da ausência de atividade mitocondrial espermática (20\%) dos espermatozoides, especialmente da cauda do epidídimo. Ressalta-se que tais achados podem contribuir para o diagnóstico clínico da brucelose canina e para a utilização do sêmen epididimário em biotecnologias da reprodução.

Palavras-chave: cães, Brucella canis, espermatozoides epididimários

\section{CASE REPORT}

Canine brucellosis is a zoonotic, chronic, infectious disease, which affects domestic and wild canids (Corrente et al., 2010). The disease has a worldwide distribution, and has been

Recebido em 9 de junho de 2016

Aceito em 20 de julho de 2016

*Autor para correspondência (corresponding author)

E-mail: cacavann@usp.br detected in America, Europe, Asia and Africa. In Brazil, the incidence of Brucella canis infection varies according to the geographic region and dog's management (Carmichael, 1990). The most common clinical signs in males are epididymitis and orchitis. However, frequently, dogs may remain asymptomatic, configuring an 
important source of brucellosis infection (Carmichael, 1990). Therefore, hidden brucellosis infection can jeopardize the use of sperm for reproductive biotechniques. Since the recovery of sperm directly from the epididymis allows for the use and storage of genetic material post-mortem or after orchiectomy, the dog has to be proven Brucella free before epididymal sperm can be processed. Hence, all forms of diagnosis should be exhaustively employed in order to guarantee the safe use of epididymal sperm of asymptomatic dogs. In this context, this case report aims to present epididymal sperm abnormalities of an asymptomatic dog affected by canine brucellosis and, thus, contribute to the overall challenge of Brucella canis diagnosis. To our knowledge, the specific modifications in epididymal sperm of dogs affected by Brucella canis have not yet been studied or established.

The current study was approved by the Bioethics Committee of the School of Veterinary Medicine and Animal Science - University of São Paulo (protocol number 2277/2011). Breeding soundness examination was performed in a mongrel dog with 2 years of age and $12.8 \mathrm{~kg}$ of body weight. Blood was collected by venipuncture and serum was utilized for the identification of brucellosis by means of the Antigen Rapid Canine Brucella $A b$ Test (Bioeasy, Minas Gerais, Brazil), which detects the anti-Brucella canis IgG antibodies, with high specificity. Physical examination revealed no remarkable change and the dog was submitted to orchiectomy. At macroscopical exam, testis and epididymides were considered normal. Epididymal sperm was collected by individual incisions of the caput, corpus, and cauda epididymides with a scalpel blade. Dissection was performed carefully to avoid sectioning of blood vessels. The flowing epididymal fluid was collected with an automatic pipette, and the total volume of the epididymal sample was resuspended in $300 \mu \mathrm{L}$ of PBS medium (phosphate buffered saline).

Samples from the epididymal segments (i.e. caput, corpus and cauda) were immediately evaluated for computer-assisted sperm analysis (CASA; HTM-IVOS Ultimate 12.3; Hamilton Thorne Biosciences, Beverly, MA, USA), according to a previously described protocol (Angrimani et al., 2014), which permitted the assessment of several sperm movement features.
Moreover, spermatozoa were evaluated for plasma membrane permeability and morphology using the eosin/nigrosin stain (Lagergren, 1953), acrosomal membrane integrity using the Fast Green-Rose Bengal stain (Pope et al., 1991) and mitochondrial activity, using the 3,3'diaminobenzidine (DAB) technique (Hrudka, 1987). The latest exam revealed four classes of sperm mitochondrial activity: high, intermediate, low, and lack of mitochondrial activity.

Regarding the sperm movement analysis, several automatized variables were below reference values for epididymal spermatozoa, such as sperm motility, percentage of progressive, percentage of rapid, velocity average pathway, curvilinear velocity, velocity straight line, amplitude of lateral head displacement, straightness, and linearity (Tab. 1). These data show a chronicity pattern of brucellosis infection, since reduced sperm motility is verified only after eight weeks of infection (Minharro et al., 2005). Moreover, sperm presented low mitochondrial activity in all three epididymal segments (Tab. 2), which can be attributed to a local epididymal infectious process (Fraczek et al., 2015). No changes in sperm plasma membrane and acrosome integrity were observed in epididymal cauda. However, corpus sperm presented high percentage of acrosome lesions (Figure 1). A high percentage of total sperm defect was observed in epididymal cauda, with special relevance to tail $(17 \%)$ and intermediate piece $(9 \%)$ defects. These data are in accordance to Larsson et al. (1984), who described an increased percentage of abnormal spermatozoa in ejaculated semen of infected dogs with brucellosis.

Sperm alterations derived mainly from epididymal cauda, suggesting that the severity of brucellosis infection is associated with prolonged exposure to the epididymal environment. In fact, epididymides can be altered by Brucellosis infection due to neutrophil exudation, leading to spermatic granuloma, fibrosis or even epididymitis (Ridler et al., 2012). Thus, we believe that the long-term exposure to bacterial toxins or local immune response at the cauda epididymides is the explanation under the increased percentage of sperm defects. Moreover, the low sperm mitochondrial activity can be attributed to brucellosis inflammatory changes, which ultimately increased the 
production of free radicals (Fraczek et al., 2015). Therefore, the decrease in sperm motility is considered a consequence of the lower energy production by sperm mitochondria (Piomboni et al., 2012).

In conclusion, Brucella canis promotes important sperm changes locally at the epididymal site, which impact morphological and functional attributes of spermatozoa in dogs. Despite the absence of clinical signs and macroscopic lesions of the testis and epididymides (orchitis and epididymitis), sperm analysis of epididymal origin revealed an important data for diagnosis purposes. Apart from serologic tests, these findings can be used to select dogs as donors for germplasm banks, improving the safe use of epididymal semen for reproductive biotechnologies. Moreover, our data is a warning for epididymal semen processing, as the suspicion of brucellosis infection has to be a part of the protocol. Furthermore, the present findings can contribute to clinical diagnosis of canine brucellosis whenever epididymal sperm analysis is undertaken (i.e. semen biotechnologies), highlighting the need for a further definite diagnosis through specific serological tests.

Table 1. Computer-assisted sperm analysis (CASA) in a dog affected by Brucella canis

\begin{tabular}{|c|c|c|c|c|c|c|}
\hline & \multicolumn{3}{|c|}{ Reference Values $^{*}$} \\
\hline & Caput & Corpus & Cauda & Caput & Corpus & Cauda \\
\hline Total sperm motility (\%) & 0 & 35 & 68 & $0.6 \pm 0.2$ & $35.4 \pm 5$ & $68.7 \pm 3.5$ \\
\hline Sperm progressive motility $(\%)$ & 0 & 4 & 20 & $0 \pm 0$ & $8.7 \pm 1.2$ & $33.7 \pm 2.1$ \\
\hline Percentage of rapid sperm (\%) & 0 & 14 & 35 & $0.1 \pm 0.1$ & $22.4 \pm 3.9$ & $54.3 \pm 4.5$ \\
\hline $\begin{array}{l}\text { Sperm velocity average pathway } \\
(\mu \mathrm{m} / \mathrm{s})\end{array}$ & 0 & 60.7 & 65.5 & $15.5 \pm 8$ & $93.3 \pm 4.6$ & $100.5 \pm 4.5$ \\
\hline $\begin{array}{l}\text { Sperm velocity straight line } \\
(\mu \mathrm{m} / \mathrm{s})\end{array}$ & 0 & 36.5 & 45 & $9.9 \pm 6.1$ & $59 \pm 5.1$ & $77.3 \pm 4$ \\
\hline Sperm curvilinear velocity $(\mu \mathrm{m} / \mathrm{s})$ & 0 & 126.7 & 119.7 & $41 \pm 19.2$ & $200.9 \pm 7.1$ & $175.4 \pm 10$ \\
\hline $\begin{array}{l}\text { Amplitude of lateral head } \\
\text { displacement }(\mu \mathrm{m} / \mathrm{s})\end{array}$ & 0 & 9.2 & 6.2 & $1.6 \pm 1.1$ & $10.2 \pm 0.3$ & $8 \pm 0.3$ \\
\hline Sperm straightness $(\%)$ & 0 & 56 & 60 & $16.4 \pm 8.1$ & $56.3 \pm 2.1$ & $71.4 \pm 1.5$ \\
\hline Sperm linearity $(\%)$ & 0 & 29 & 36 & $9 \pm 4.8$ & $29.1 \pm 1.8$ & $44.6 \pm 2.1$ \\
\hline
\end{tabular}

Table 2. Epididymal sperm analysis of a dog affected by Brucella canis

\begin{tabular}{lccccccc}
\cline { 5 - 7 } & \multicolumn{4}{c}{} & \multicolumn{4}{c}{ Reference Values } \\
\hline Intact plasma membrane (\%) & Caput & Corpus & Cauda & Caput & Corpus & Cauda \\
Intact acrosome membrane (\%) & 40 & 92 & 97 & $64 \pm 2.3^{*}$ & $77 \pm 2.3^{*}$ & $87 \pm 1.7^{*}$ \\
High mitochondrial activity (\%) & 43 & 77 & 93 & $67 \pm 1.8^{* *}$ & $82 \pm 1.2^{* *}$ & $90 \pm 0.6^{* *}$ \\
Intermediate mitochondrial activity (\%) & 30 & 30 & 4 & $21.6 \pm 1.9^{* *}$ & $17.4 \pm 1^{* *}$ & $9 \pm 1.1^{* *}$ \\
Low mitochondrial activity (\%) & 30 & 20 & 4 & $13.2 \pm 1.6^{* *}$ & $9.3 \pm 1.2^{* *}$ & $2.9 \pm 0.6^{* *}$ \\
Absence mitochondrial activity (\%) & 34 & 30 & 20 & $39.5 \pm 3.6^{* *}$ & $26.2 \pm 3^{* *}$ & $12.5 \pm 3^{* *}$ \\
Total Defects (\%) & 73 & 53 & 51 & $88 \pm 1.6^{* *}$ & $41 \pm 4.5^{* *}$ & $31 \pm 5.4^{* *}$ \\
\hline
\end{tabular}

${ }^{*}$ Adapted from Angrimani et al. (2014) / ${ }^{* *}$ Adapted from Angrimani (2013) 


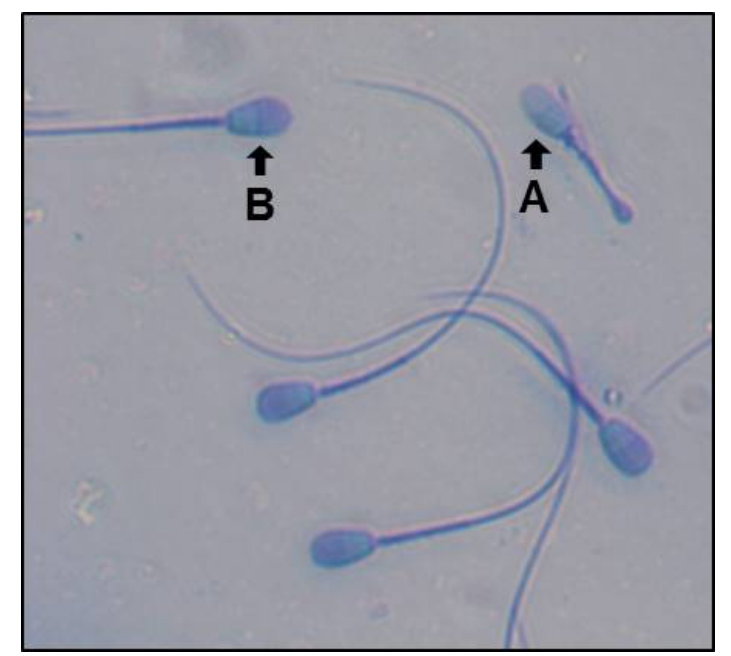

Figure 1. (A) Acrosome lesion of spermatozoa harvested from the corpus epididymides of a dog infected with brucellosis (acrosomal region is unstained or brighter than the post-acrosomal area). (B) Intact sperm (acrosomal region stained in purple or darker than the post-acrosomal area). Fast Green/Rose Bengal technique. Bar scale: $10 \mu \mathrm{m}$.

\section{REFERENCES}

ANGRIMANI, D.S.; LUCIO, C.F.; VEIGA, G.A. et al. Sperm maturation in dogs: sperm profile and enzymatic antioxidant status in ejaculated and epididymal spermatozoa. Andrologia, v.46, p.814-819, 2014.

ANGRIMANI, D.S.R. Estudo da maturação epididimária em cães. 2013. 148f. Dissertação (Mestrado em Ciencia Animal) - Departamento de Reprodução Animal, Universidade de São Paulo, São Paulo, SP.

CARMICHAEL, L.E. Brucella canis. In: DUCAN, J.R. (Ed.). Animal brucellosis. Boca Raton: CRC Press, 1990, p.335-350.

CORRENTE, M.; FRANCHINI, D.; DECARO, N. et al. Detection of brucella canis in a dog in Italy. New Microbiol, v.33, p.337-341, 2010.
FRACZEK, M.; HRYHOROWICZ, M.; GACZARZEWICZ, D. et al. Can apoptosis and necrosis coexist in ejaculated human spermatozoa during in vitro semen bacterial infection? J. Assist. Reprod. Genet., v.32, p.771779, 2015.

HRUDKA, F. Cytochemical and ultracytochemical demonstration of cytochrome c oxidase in spermatozoa and dynamics of its changes accompanying ageing or induced by stress. Int. J. Androl., v.10, p.809-828, 1987.

LAGERGREN, C.G. On the eosin-nigrosin stain and some other methods for the appraisal of sperm vitality with special reference to practical application. Ann. Obstet. Ginecol., v.75, p.9981005, 1953.

LARSSON, M.H.M.A.; BARNABE, V.H.; VISINTIN, J.A. et al. Alterações do quadro espermático do cães infectados experimentalmente com Brucella canis. Rev. Fac. Med. Vet. Zootec. Univ. S.P., v.21, p.75-63, 1984.

MINHARRO, S.; COTTORELlO, A.C.P.; MIRANDA, K.L. et al. Diagnóstico da brucelose canina: dificuldades e estratégias. Rev. Bras. Reprod. Anim., v.29, p.167-173, 2005.

PIOMBONI, P.; FOCARELLI, R.; STENDARDI, A. et al. The role of mitochondria in energy production for human sperm motility. Int. J. Androl., v.35, p.109-124, 2012.

POPE, C.E.; ZHANG, Y.Z.; DRESSER, B.L. A simple staining method for evaluating acrosomal status of cat spermatozoa. J. Zoo Wildl. Med., v.22, p.87-95, 1991.

RIDLER, A.L.; WEST, D.M.; COLLETT, M.G. Pathology of brucella ovis infection in red deer stags (Cervus elaphus). N. Z. Vet. J., v.60, p.146$149,2012$. 